\title{
"THERE IS NO WHITE FLAG AND NO CHANCE OF GOING TO JAIL!" THE VIOLENT RELATIONS BETWEEN POLICE AND CRIMINALS IN FACÇÃO CENTRAL'S RAP SONGS
}

\author{
"Não Tem Bandeira Branca, "¡No Hay Bandera Blanca, \\ Nem Chance de Ir Pra Grade!" No Hay Oportunidad de Ir a la Prisión!" \\ - As Relações Violentas - Relaciones Violentas \\ entre Polícia e Criminosos nos Raps entre la Policía y los Penales en las Raps \\ do Grupo Facção Central del Grupo Facção Central
}

\author{
Bruno de Souza Lessa* \\ Universidade de Fortaleza \\ Fortaleza, CE, Brazil \\ Ana Clara Aparecida Alves de Souza** \\ Pontifícia Universidade Católica do Rio Grande do Sul \\ Porto Alegre, RS, Brazil
}

\begin{abstract}
This paper analyzes the relationship between police brutality and its repercussion in the narratives exposed by Brazilian rappers in their lyrics. The central argument is that such violence is not a consequence or a cause for the phenomenon, but a structural element in the dynamics of urban violence. Such violence is essential for establishing the "Us VS. Them", logic that objectifies itself in the feuds between police officers and criminals, expressed by the lyrics scrutinized here. Methodologically, the historical-discursive approach of Critical Discourse Analysis was employed. The analytical basis were the procedures suggested for text analysis and the focus of the investigation was the lyrics from the rap band Facção Central. The recursive relation between criminals and police officers was highlighted, in which violence functions as a mediating instrument. Violence between these groups emerges as a solidary element, i.e., it is the social cement providing cohesion to the interaction between these groups.
\end{abstract}

Keywords: Critical Discourse Analysis. Historical-Discursive Approach. Rap Music. Brazil.

Resumo: 0 artigo analisa a relação entre a violência policial e sua repercussão nas narrativas expostas por rappers brasileiros em letras de músicas. 0 argumento central é que a violência apresentada pelos artistas é um elemento estrutural na dinâmica da violência urbana no seu sentido mais amplo. Essa violência é essencial para o estabelecimento da lógica "Nós versus Eles", que se objetiva nos enfrentamentos entre policiais e criminosos, algo que se expressa nas letras escrutinadas neste trabalho. Metodologicamente, o estudo utiliza a abordagem histórico-discursiva da Análise Crítica do Discurso. Toma como base os procedimentos sugeridos para análise de textos e investiga como as letras de rap do Grupo Facção Central descortinam a relação recursiva entre

\footnotetext{
* $\mathrm{PhD}$ in Management for the Federal University of Rio Grande do Sul. Postdoctoral fellow at the Postgraduation Program in Management of the Universidade de Fortaleza (Unifor). ORCID: http://orcid.org/0000-0002-1696-394X. E-mail: brunolessa85@yahoo.com.br.

** $\mathrm{PhD}$ in Management for the Federal University of Rio Grande do Sul. Postdoctoral fellow at the Postgraduation Program in Management of the Pontifícia Universidade Católica do Rio Grande do Sul (PUCRS). ORCID: https://orcid.org/0000-0001-5574-2560. E-mail: clara.ufc@gmail.com.
} 
criminosos e policiais, na qual a violência serve como instrumento mediador. A violência entre os grupos emerge, aqui, como elemento solidário, isto é, o "cimento social" que dá coesão à interação desses grupos.

Palavras-chave: Análise Crítica do Discurso. Abordagem Histórico-Discursiva. Rap. Brasil.

Resumen: El artículo analiza la relación entre la violencia policial y su repercusión en las narrativas expuestas por rappers brasileños en letras de músicas. El argumento central es que la violencia presentada por los artistas es un elemento estructural en la dinámica de la violencia urbana en su sentido más amplio. Esa violencia es esencial para establecer la lógica "Nosotros versus Ellos", que se hace objetiva en los enfrentamientos entre policiales y criminales, algo que se hace expreso en las letras escrudiñadas en este trabajo. Metodológicamente, el estudio utiliza el abordaje histórico-discursivo del Análisis Crítico del Discurso. Toma como base los procedimientos sugeridos para análisis de textos e investiga como las letras de rap del Grupo Faç̧ão Central descortinan la relación recursiva entre criminales y policiales, en la cual la violencia sirve como instrumento mediador. La violencia entre los grupos emerge, aquí, como elemento solidario, es decir, el "cimento social" que da cohesión para la interacción de eses grupos.

Palabras clave: Análisis Crítico del Discurso. Abordaje Histórico-Discursivo. Rap. Brasil.

\section{INTRODUCTION}

Rap Music has recently ceased to be only a marginal or nearly criminalized cultural manifestation to a broader extent in the US and, to a lesser degree, in Brazil. This assertion can be empirically witnessed and sociologically proved, by the fact Rap has been gradually been accepted in commercial entertainment markets in both countries. Even though it has been inserted in mainstream contemporary music markets, rap still have a strong role in big cities' peripheries in cities such as São Paulo and Chicago a way for vulnerable and yet marginalized groups to express their dissatisfaction with the position they occupy in the social space (RICHARDSON, 2007; TEPERMAN, 2015a, 2015b; HELLAND, 2017). In this sense, for instance, it is through rap that these individuals reveal themselves in Brazil, insofar as they tend to be the systematic victims of the structurally violent dynamics constituting Brazilian inequalities and racism.

Thus, such structural violence cannot be understood as a contemporary phenomenon, given it draws back to a tradition in treatment and forms of ruling that have already been evidenced in the classics of Brazilian social thought. In this socio-historical perspective, it can be argued that violence serves, to a large extent, as a connecting element in the dynamics established between dominant and dominated social groups (ADORNO, 2002a, 2002b). Violence frames the social relations settled between State repressive apparatuses, namely, the police and its branches, and marginalized groups, i.e., those considered criminals according to societal laws and norms (ADORNO, 2002a, 2002b; ALMENDRA; MORAES, 2012).

Considering these elements, this paper aims to scrutinize these violent dynamics, taking as means of investigation the forms rappers from the Facção Central (FC) group describe and explain they in their lyrics. By doing so, we defend a double-folded argument. First, the violence spelled out in the lyrics functions as an element of solidarity in the Durkheimian sense (DURKHEIM, 1999) that integrates these two groups, as it would be the "social cement" mediating and giving cohesion to their relationship. Second, we argue that violence is fundamental in maintaining the logic of "Us vs. Them" which, 
in turn, frames the relations between police officers and criminals and that have been crystallized in the modes of social interactions observed in Brazilian society between these two groups.

This rap group was chosen for the following reasons. First, FC has been considered, by the literature addressing the subject, as one of the most representative groups in Brazilian national rap alongside with the Racionais MCs (LOUREIRO, 2017; CAMARGOS, 2017; SAMYN, 2018; GOMES, 2018). Second, the Group's confrontational positions against the State repressive apparatuses (ALTHUSSER, 1980) have been widely documented, starting at its lyrics and going to its music videos and interviews. This second point is reinforced, for example, by the censorship FC suffered in the $2000 \mathrm{~s}^{1}$, when a court decision banned temporarily the broadcast of one of their clips on TV. Third, their lyrics portray the kind of antagonism intended to be evidenced in this paper. Finally, aligning with the classification brought forth by Teperman (2015a, 2015b), FC subscribes to a revolutionary rap, once it is explicitly engaged with the denunciation and radical subversion of Brazilian social structures.

Methodologically, we employed the Critical Discourse Analysis (CDA) along the lines suggested by Wodak $(2007,2009)$ and Wodak and Meyer (2007) to highlight the relations intended to be observed in the lyrics. The corpus focused on songs from the following albums: Direto do Campo de Extermínio (Straight from the Death Camp in Portuguese) and O Espetáculo do Circo dos Horrores (The Horror Circus Show in Portuguese) released in 2003 and 2006, respectively. The songs were: Eles vão ter que algemar meu cadáver, Quando Eu Sair Daqui, O Espetáculo do Circo dos Horrores and Estrada da Dor 666 (They'll have to handcuff my corpse, When I get outta here, The Horror Circus Show and Pain Road 666 in Portuguese).

This article is divided into six sections. After this introduction, there is a brief contextualization of Rap Music, focusing on the Brazilian context. In this segment, we do not only stress the importance of scrutinizing rap as a cultural manifestation, but also the relevance of analyzing the role of rappers in the objectification of the structural violence brought about by the State and its extensions, since these artists have objectively lived the experiences they report through their songs. The third section then details in theoretical and methodological terms the selected CDA conception, emphasizing its relevance to the type of study carried out here. Afterwards, the fourth section outlines the methodological procedures that enabled operationalizing this work. The analysis of the lyrics and the intertwined discussion with the argument are presented in the fifth section. Finally, the last section offers our concluding remarks.

\footnotetext{
${ }^{1}$ On June 29 2000, the Judge Mauricio Lemos Porto Alves from the Technical Department of Police Inquiries and the Judicial Police ordered the seizure on MTV of the original music video tape Isso aqui é uma Guerra (This is a War in Portuguese) vetoing its performance. The ruling was based on the accusation the clip would incite theft, kidnapping, illegal possession of weapons and the release of imprisoned individuals, glamourizing the success of criminal operations. In addition, prosecutors accused the video of inciting racism, as the criminals depicted in the clip were black, and prejudice against residents of São Paulo East Side, who are also identified as criminals. Source: https://www1.folha.uol.com.br/folha/ilustrada/ult90u1598.shtml. Accessed on: 29/07/2019.
} 
The social problem this paper addresses is a phenomenon of the context of which it has been an integral part, however, it is also one of its integrative components. Thus, we argue that the violence settled between police forces and criminals is a framing part of both the social dynamics and the historical (and racial) inequalities constituting Brazilian societal life.

Nonetheless, it is noteworthy that once Rap is used as a means of expression for marginalized groups such as the people living in Brazilian poor neighborhoods and slums, who also are the most direct victims of the consequences of such inequalities. Moreover, the rhythm does also express a strong protagonism from these very actors. In this regard, they do not appear only as victims, but also oftenly as artisans of a more complex dynamics holding prolongations and radiations in several fundamental institutions in society (TEPERMAN, 2015a, 2015b).

Whether in Brazil or abroad, the stories narrated in rap songs are often inseparable from the biographical trajectories of the ones who perform them. Both when rappers announce their own objectification or when they describe others' trajectories, their dissatisfactions and sufferings become evident through lyrics that are rarely presented as figurations of a romantic epic tale such as the ones shown in the Scadinavian Beowulf or in Homer's Odissey, but rather as concrete and reality-relatable stories like the ones presented in NWA, Tupac or in Racionais MCs' songs (RICHARDSON, 2007; TEPERMAN , 2015a, 2015b HELLAND, 2017; SAMYN, 2018).

In the rap songs denouncing the conflict between State and marginalized groups, such as the ones that served as the basis for this paper, a commonly used analogy is with the event of a war, which can be seen in the title and lyrics of songs like FC's Isso aqui é uma Guerra or A Guerra não vai acabar (This is War and The War is not going to end in Portuguese). In this sense, the analogy with the open armed conflict between rival groups signals that the end of a quarrel would not be the resocialization of those involved, and neither would it be its resolution followed by the likely return to ordinary activities (LOUREIRO, 2017; CAMARGOS, 2017; GOMES, 2018). Such analogy systematically would be better drawn on the notion of Total War, as used by Eric Hobsbawm (1995), that is, the conflict only comes to an end after the complete annihilation of the enemy in combat.

From this perspective, the rapper Eduardo Taddeo's account might work an appropriate depiction. In his book as well as in this lyrics, the FC member reports that the result of the carnage brought about by the police in the poorer communities unveils the experience of a perennial state of siege in Brazil, especially at territories dominated by drug trafficking. According to Taddeo, this observation would be the most applicable to Brazilian reality insofar as what is actually observed is that such tool has been employed permanently, differently of the conceptualization contained in the article 137 of the 1988 Federal Constitution, which introduces the state of siege as a temporary tool at government's service. To the rapper, the success of anti-crime public policies is sustained by actions in which policemen "invade houses, make arrests without warrants, forbid meetings and public demonstrations, prevent access to 'inappropriate content' to insurgent-minded citizens. It tortures, slaughters, hangs, shoots people and hide their bodies" (TADDEO, 2012, p. 76-77). 
Furthermore, this social context is built upon the historical different forms of governmental violence. They emerge as social controls especially over the most impoverished populations, a characteristic intensified by the police use of torture and by the actions of vigilante groups in public security agencies during the civil-military dictatorship period (1964-1985). These last two elements, namely, the use of torture and the action of vigilante groups, persisted in the democratic regime, once they were not effectively fought within and by public security agencies. Such violence also belongs to a secular tradition, which can be traced back to the choice for maintaining the slave order, for resolving conflicts related to land control. In addition, governmental violence would be sustained on a hierarchical and paternalistic conception of citizenship, based on a cultural opposition between The Good vs. The Bad, that is, between law-abiding citizens against all criminalized populations. Hence, the maintenance of the status quo and of public order have become intertwined (RIGON; FRANCE, 2014).

Taking into consideration the aspects above, the critical discourse analysis approach chosen to operationalize our efforts was the one systematized by Ruth Wodak and her colleagues (WODAK, 2007, 2009; WODAK; MEYER, 2007). We chose such approach because of our emphasis on this Us vs. Them dynamics, which is fundamental for the argumentation brought forward here. In other words, this approach was adopted because it is an appropriate methodological tool to highlight the arguments serving as the basis for this research. Therefore, the next section aims to further detail it.

\section{THE HISTORICAL-DISCURSIVE APPROACH}

Exclusion policies and practices are inherent and, to a certain extent, almost necessary for the existence of the capitalist society. Nevertheless, inclusion and exclusion cannot be explicitly displayed for one basic reason: the former has such a diffuse ideological value in capitalist societies that the explicit enunciation of exclusionary policies conflicts directly with such value (WODAK, 2007, 2009; WODAK; MEYER, 2007). Inclusion and tolerance have been constitutive values of liberalism at least since the works of John Locke (1632 - 1704) and, as such, words like 'discrimination' and 'exclusion' carry a strong negative connotation. Therefore, despite the implementation of inclusive policies, inequality persists to the extent it is also structural to Brazilian society. This is why movements and processes related to inequality, such as violence between police and criminals, can be investigated through the ideological characters presented in different speeches.

The corpus selected here allowed us to move in another direction as FC's lyrics do not hide the conflict between the police force and criminals. On the contrary, conflicts appear unveiled in all its recrudescence and these lyrics make apparent what remains seemingly latent in urban conflicts. In addition, these songs provide a clear and detailed description of the actions of each group, both policemen and criminals.

This different corpus creation as well as its analysis does not only underline this study's relevance, but also underscores how discursive practices are capable of consolidating violence in its most diverse facets. Although it does not seem so, violence becomes the normal accepted and integrated into all dimensions of social life (ADORNO, 
2002a, 2002b). It takes place as a background phenomenon or even in speech acts, in social norms or legislations. Although, these legal controls are of fundamental importance for maintain order in capitalism, the resort to violence also has an important role as part of the global capitalist system, so that the system turns out creating and requiring discourses to justify and deal with it. In a sense, capitalism and its inequality need violence to be effective.

The historical-discursive approach deals with three dimensions of discourse. First, it establishes the specific topics and contents of discourse. Second, it scrutinizes the discursive strategies, including different ones for argumentation. In the third dimension, context-specific and language-specific media and performances are categorized and related to previous dimensions. In the analysis, historical developments, structural norms and institutions are also taken into account. In order to scrutinize the lyrics selected for this work, we selected five elements from the approach that functioned as guiding categories for the analytical process (WODAK; MEYER, 2007).

Five types of strategies are analyzed here, it is relevant to emphasize they are enmeshed in both the positive and negative representations the groups have of each other. These discursive strategies underpin the justification and legitimation of the use of violence and identity construction for both groups. From this perspective, strategy means a more or less precise or intentional form of a practice, encompassing discursive practices adopted to achieve a social, political, psychological or linguistic goal (WODAK, 2007, 2009).

First, there are referral or naming strategies aiming to build or represent social actors. This is done in the following ways: by categorization devices such as metaphors and metonymies, as well as by synecdoches, that is, when the whole corresponds to one of the parts or vice and versa. This is possible because social actors as individuals are members of groups and these groups are linguistically characterized by predication. Second, there are predication strategies employed as classificatory attributions for negative or positive traits manifested through linguistic forms such as implicit and explicit predicates. Third, there are argumentative strategies demonstrating a topoi basis by which certain positive and negative attributions are then justified. As such, violence can be justified by being sustained on legitimate grounds (WODAK, 2007, 2009).

Fourth, the perspectivation, framing, or representation of the discourse has an essential function, as it serves to analyze how those who speak assert their involvement in discourse and posit their views. Finally, intensification and mitigation strategies qualify or modify the epistemic status of a proposition as it increases or decreases the force of utterances (WODAK, 2007, 2009). The next section, which details the methodological procedures, further clarifies how these categories were applied to the selected material.

\section{METHODOLOGICAL PROCEDURES}

This work uses lyrics from Facção Central's rap songs in its operationalization in order to accomplish its central objective, namely, to demonstrate the role of violence as a solidary element in the establishment of the antagonistic rationale settled between police forces and criminals. These lyrics illustrate different moments in the confrontations 
between these groups and, thus, make possible both a greater descriptive width and broader analytical perspective, considering this paper's goals.

The songs selected were Eles vão ter que algemar meu cadáver, Quando Eu Sair Daqui, O Espetáculo do Circo dos Horrores and Estrada da Dor 666 from the records Direto do Campo de Extermínio and O Espetáculo do Circo dos Horrores (They'll have to handcuff my corpse, When I get outta here, The Horror Circus Show and Pain Road 666 in Portuguese) released in 2003 and 2006, respectively. It is noteworthy that the temporal distance between the years these records were released and our present contemporaneity does not affect the central axis neither of the compositions between themselves nor of this paper, insofar as the regularities permitting them to be approximated still persist in Brazil nowadays. This statement actually means that in structural and historical terms, Brazilian social reality remains almost untouched regarding the violent sociabilities engendered between the groups studied. As previously stated, despite dealing with different moments of interaction between groups, the songs chosen keep the centrality of violence, inequality, discrimination and antagonism among the protagonists appearing in the narratives.

Furthermore, the lyrics were analyzed based on the five categories detailed in the previous section, following the procedures described by Wodak $(2007,2009)$ and Wodak and Meyer (2009). In other words, the lyrics' elements are described and analyzed through those five categories in order to support the argument and achieve the objectives this paper has been built upon.

The first category, referential or naming strategies, analyzes metaphors, metonyms, and synecdoches that discursively qualify determined groups. The second, predication strategies, emphasize the linguistic forms introducing negative and/ or positive characteristics through which the protagonists outline themselves. The third category, argumentative strategies, brings to light the fundamental topos justifying positives and negatives statements actors make about themselves and their antagonists. Fourth, the manner in which those involved depict themselves in discourse are demonstrated and analyzed in the category called perspectivation, framing, or representation of the discourse. Finally, the intensification and mitigation strategies scrutinize how actors stress or soften the epistemic condition of what they claim about themselves and others displayed in the songs. These five categories are summarized in Table 1.

Regarding the analysis, some of these categories were clustered for the following reasons. First, we understood that the referral or naming and the predication strategies effectively came together in the forms presented in the lyrics. In this sense, it was possible to avoid the redundancy that could emerge if these aspects were separated. Moreover, we interpreted that references and nomenclatures have been charged with positive and negative meanings, inasmuch as they are also kinds of predication. Hence, these two points have been analyzed in an integrated manner. This same reason led us to analyze the fourth and fifth categories in the same topic, once the perspective, framing or representations of the discourse and the intensification and mitigation strategies emerged conjointly in the lyrics. This has been done so because the perspectives or framings in the lyrics are filled with intensifications and mitigations about the actors, feature which also disallowed the separation of these two instances at the risk of falling into making the analysis redundant or even fragmented. 


\begin{tabular}{|c|c|c|}
\hline Strategy & Objectives & Devices \\
\hline Referential or naming strategies & $\begin{array}{l}\text { Construction of in-groups } \\
\text { and out-groups }\end{array}$ & $\begin{array}{l}\text { - Membership categorization } \\
\text { - Biological, naturalizing and } \\
\text { depersonalizing metaphors and } \\
\text { metonymies } \\
\text { - Synecdoches } \\
\text { (pars pro toto, totum pro pars) }\end{array}$ \\
\hline Predication strategies & $\begin{array}{l}\text { Labeling social actors } \\
\text { more or less positively } \\
\text { or negatively, } \\
\text { deprecatorily or } \\
\text { appreciatively }\end{array}$ & $\begin{array}{l}\text { - Stereotypical, evaluative } \\
\text { attributions of negative or } \\
\text { positive traits } \\
\text { - Implicit and explicit predicates }\end{array}$ \\
\hline Argumentative strategies & $\begin{array}{l}\text { Justification of positive } \\
\text { or negative attributions }\end{array}$ & $\begin{array}{l}\text { - Topoi } \\
\text { used to justify inclusion or } \\
\text { exclusion, discrimination, or } \\
\text { preferential treatment }\end{array}$ \\
\hline $\begin{array}{l}\text { Perspectivation, } \\
\text { framing, or discourse } \\
\text { representation }\end{array}$ & $\begin{array}{l}\text { Expressing involvement } \\
\text { Positioning speaker's } \\
\text { point of view }\end{array}$ & $\begin{array}{l}\text { - Reporting, description, } \\
\text { narration, or quotation of events } \\
\text { and utterances }\end{array}$ \\
\hline $\begin{array}{l}\text { Intensification, } \\
\text { Mitigation }\end{array}$ & $\begin{array}{l}\text { Modifying the epistemic } \\
\text { status of a proposition }\end{array}$ & $\begin{array}{l}\text { - Intensifying or mitigating the } \\
\text { illocutionary force of utterances }\end{array}$ \\
\hline
\end{tabular}

Table 1 - Discursive strategies for positive and negative representations of self and others Source: Adapted from Wodak (2007).

Therefore, based theoretically, methodologically and operationally on what has been proposed so far, the following section presents the analysis focusing on each of the categories introduced above.

5 ANALYSIS OF RESULTS

This section has the objective to analyze FC's lyrics by taking advantage of the five categories mentioned in previous sections. Those categories enabled to use the lyrics as a platform to expose the social relations aimed to be studied in this paper. In order to achieve our central objective and support our argument, we examined the songs through the five categories underpinning Wodak (2007, 2009) and Wodak and Meyer's (2007) historical discursive approach to Critical Discourse Analysis.

\subsection{REFERRAL OR NAMING STRATEGIES AND PREDICATION STRATEGIES}

We employ metaphors, metonyms and synecdoches in the most different modes of communication, and their function is to show how social agents differ from one another. These figures of speech serve also as forms to give identity to those whom we mean to qualify. Moreover, such figures assist us to identify ourselves insofar as they help us to distinguish from others (WODAK, 2007, 2009; WODAK; MEYER, 2007). In this perspective, the same happens with the social actors represented in the lyrics. It is by qualifying specific dichotomies the songs' protagonists express themselves, showing they are simultaneously active and passive agents in the interactions they narrate. 
In FC's lyrics, the police receive popular Brazilian nicknames, but the systematic use of profanities referring to them is actually more frequent. The colloquialism gambé (cop in Portuguese) is used more systematically, as alias which has been historically employed to address to policemen, but much more energetic ones oftenly emerge as the word cu (asshole in Portuguese). In the beginning of the song When I get outta here, a prison riot is described as "Hatred on the edge lit just like dynamite / In hell, the crisis explodes / On the wall, an asshole with a rifle". In this case, the one who prepares to shoot from the top of the wall with his rifle, the so-called "ass", is precisely the police officer allegedly responsible for safeguarding the prisoners' lives during the riot. In the situation described, criminals are perpetrators and victims of both their own violence and from the response coming from the police.

In Pain Road 666, this mode of classification is further reinforced. In the clashes with the Military Police (MP) the most likely outcome becomes the complete elimination of one of the groups, with no possible conciliation. Such perspective appears when the rappers announce: "When your body starts decomposing in the scrubs / do not even expect an ass with a newspaper to cover it".

The other lyrics intensely repeat this naming strategy. In the song They'll have to handcuff my corpse, the chorus makes it clear that "there is no white flag, no chance of going to jail / the ass will have to handcuff my corpse". Eliminating the other would be the only viable alternative in this conflict, as they are both aware they are in a war in which the goal is to kill before getting killed. This aspect is even clearer in the verses when the police is told that "[He] Did not come to play, did not come to handcuff / If the vulture does not see carrion, it will not settle down". Furthermore, in this segment, police officers are referred to as urubus (vultures in Portuguese), that is, the police forces in their entirety would be equal to rotting meat-eating animals. The animal loses its imposing qualities as a bird of prey, to become only an animal which eats what others do not have the guts to digest.

It is noteworthy that if, on the one hand, policemen are referred to as vultures, on the other hand, criminals are represented by courageous and fierce animals. In the Horror Circus Show, this form of representation is made explicit when it is stated "The tiger kills the tamer, besets the district / Recovers the arsenal from the seized storeroom". Through this circus metaphor, it is established that the actors in such scenario continue in opposite fields and identify one another based on their positions in such social space. It is in this sense the composers explain that "The apple the knife thrower divides / It's the one on the face of the D.I.G [General Investigations Police Station in Portuguese] deputy".

\subsection{ARGUMENTATIVE STRATEGIES}

In order to become intelligible and acquire legitimacy, speeches must also be grounded in positions about those who are mentioned in them. These arguments are not, however, axiologically neutral, insofar as they convey an implicit or explicit value judgment about the actors displayed. This positioning develops itself from arguments taking place through structures called topos or topoi. It is a geographical metaphor in which argumentation allows to situate actors and, thus, to define them. Topoi are essential 
for settling actors in the social world and to justify their predications. In this sense, the topos of definition was the main one appearing in the songs given that there is a constant delineation of the elements making the police what they are, as well as there is the continuous presentation of aspects positioning the criminals as such. Therefore, predications, position takings, and definitions are inseparable elements in discourse construction (WODAK, 2007, 2009).

The topos of definition outlines who the actors are and how they act (WODAK; MEYER, 2007). For example, in They will have to handcuff my corpse, police's defining practices are the ones the most potentially lethal, and the criminals' responses described in the song, which narrates a failed robbery attempt, must be proportional. To the extent that the police functions and acts effectively as the armed hand of the State, prepared to exterminate those it faces, its antagonists must operate likewise. This is clear when the narrator comments "Now it's too late, the laser sight marks my forehead / a slight touch on the trigger 'pla! pla!' I'm gone!". Nonetheless, the narrator stresses that since he has been vulnerable against police action, his response will be equally violent, even if that implies to kill himself in the process, something expressed when he mentions: "I will throw myself in the river to get drown / I prefer to float in the shit than to see a decorated gambé”.

Following this perspective, the police forces interacting with criminals and with the incarcerated carry specific violent definitional characteristics, i.e., if the regular police forces are violent on the streets, the elite groups interacting with criminals and prisoners will have to be even worse. In this regard, the greater use of violence is the hallmark of these elites. Although they are an integral part of the force, these graduated groups tend to be more aggressive, and it is exactly this aggressiveness that sets them apart from the rest of the force. In When I Get Outta Here, for example, these elite groups' actions are presented with anger and fear: "Fuck! It's the 'choque ${ }^{2}$ '! Here comes perverse retaliation / The bourgeois' puppy throws the party".

Regarding the strategies through which Criminals argue about themselves, it is relevant to underline that the future horizon identifying these individuals is usually the one of death or, at the best hypothesis, imprisonment due to their lives of permanent confrontation against the State repressive apparatuses. In addition, this potential trajectory is fundamental for these protagonists to identify as part of their own group. In Pain Road 666 , the narrator says, "No one puts a 'file' [a crime] and gets regenerated with the profit / he ends with a MP watching over a wall". The Narrator is emphatic in claiming the validity of the common knowledge that criminal activity does not pay off, its profits do not regenerate anyone, and such trajectory ends up in a jail cell. Nevertheless, it is this very trajectory which defines these actors and their role in the social world.

Furthermore, these violent interactions are imperative to characterize how Brazilian sociabilities have been historically constructed. In the Horror Circus Show, these antagonisms extend throughout Brazilian History and reverberate not only in the relations

\footnotetext{
${ }^{2}$ In Brazil, the elite group in charge for prison pacification and control during riots is called "choque" (shock in English). This group is also responsible for social control in the case of civil demonstrations. They have been renowned in Brazilian imaginary for their violent outbursts and procedures against both incarcerated populations and civil protesters.
} 
between police forces and criminals, but also in other class struggles. Following this line of reasoning, the poet makes the following statement: "Respectable audience with pride I present / The spectacle on display since April 1500 [month and year the Portuguese arrived in Brazil] / No popcorn, cotton candy, let the drums drum / The curtains of the horror circus are now open!”.

\subsection{PERSPECTIVE, FRAMING OR REPRESENTATIONS OF THE DISCOURSE AND INTENSIFICATION AND MITIGATION STRATEGIES}

This section deals with the strategies actors utilize to qualify their involvement in discourse and to situate their views (WODAK, 2007, 2009; WODAK; MEYER, 2007). In order to give more concision to the analysis, these last two categories were integrated. Thus, in addition to the issues related to involvement and positioning, the analysis of the strategies used to intensify or reduce the strength of utterances was also added. In summary, perspective, framing or representation of discourse and intensification and mitigation strategies have been scrutinized together. This avenue was chosen to reduce the risk of possible redundancies or fragmentations once we realized perspectives and framings are charged with intensifications and mitigations about social actors, so these two instances were deemed to be entwined.

The manner in which rappers denote their involvement and situate themselves is patent in They will have to handcuff my corpse when the narrator states, "If I say I have pity, I'm lying / The hostage can beg, cry, and I kill him laughing!". In addition to the intrinsic involvement with the kidnapping described in the song, the violent conduct is intensified and its expansion is highlighted when the narrator elucidates how part of his work is done: "I throw alcohol, set fire, fuck him off! If you doubt it, I even give the pieces to my dogs". The kidnapping culminates in the hostage's death; however, it does not happen fast. It takes place through an extremely violent procedure, in which all the narrator's rage and social frustration is fully discharged upon his victim. The victim's torture and violent death can be interpreted as a form of revenge against historical inequalities and all the sufferings such inequalities encompass.

In the Horror Circus Show, the narrator's position in the social world, his point of view, and his involvement are expressed in the same way when he compares the slum where he lives to a war zone. The context described is one of a total war, one where everyone is against everyone, inasmuch as the narrator emphasizes there are "Conflicts, cultural, religious groups / The third war has just not been registered". Hence, if the two great wars were the conflicts in which the greatest number of people died in the documented history of mankind (HOBSBAWM, 1995), the one in which the narrator is inserted has the same proportions for him. For this reason, he does not hesitate to inflate certain figures about homicides, claiming that "Here, three per cent of the world's population / And thirteen per cent on the global ranking of the dead".

"When I get outta here" follows the same denunciative logic. The narrators' position in relation to society, as well as to the police, is highlighted when the narrator states: "I will share with society everything I learned / the playboy will not sleep when I 
get outta here [the prison]". The intensity of violence is further heightened when the narrator compares himself to the Devil to say that even Lucifer would not have a similar evil within: "If the Devil limps, he'll dance at the mouth of the bottle / In a thong and shaved eyebrows". Moreover, as the narrator puts himself on the victims' side, this movement is both intense and ambiguous, insofar as the victim also suffers greatly from the perpetrator's violent outbursts. The narrator employs violence to a hyperbolic degree in order to unload all his anger and emphasize his views as well as his involvement with Brazilian social reality.

Nonetheless, in Pain Road 666, this connection and positioning shifts to a regret of a life of crimes and violence. In such a way that the narrator even resorts to science fiction to stress the lack of concrete social conditions for him to be actually transformed, feature that emerges when the narrator points out: "I wanted to imitate Michael J. Fox in Back to the Future / Go Back in Time and avoid a lot of pain and grief". In spite of that, social reality is structured in a way that poverty and its consequences seem inescapable to criminals inasmuch as the life of an average worker would offer little: "The game is clear, bloodthirsty and objective / I will be a slave to a boss or a number in a prison". Therefore, in a cyclic and recursive manner, what is left for the protagonist is apparently (and unfortunately) one of these two alternatives, or worse, death.

\section{CONCLUDING REMARKS}

This work performed a discourse analysis of Facção Central's lyrics, shedding light on the representation of the conflict between detainees, criminals and poor people against the police force. In this regard, violence was presented here as an essential element in the dynamics portrayed in such conflict. Furthermore, solidarity was conceptualized here as the "social cement" enabling and maintaining cohesion among these groups. Nevertheless, such cohesion was not interpreted in the sense of consensus building, but rather in the establishment of the antagonistic relations permitting each group to be identified as such. Roughly speaking, these identifications happen through and in the articulation with relationships expressed by the logic of Us vs. Them, Police vs. Criminals or Law-abiding Citizens against Criminals.

These dynamics do not only take place when these groups confront each other, but it manifests itself in other social practices such as the most varied forms of discourse. Thus, this paper drew on the lyrics from the rap group Facção Central to demonstrate how the logic of Us vs. Them is described for those who are also its protagonists. As such, rap emerges and develops as one of the rebellious forms of expression from marginal and vulnerable populations, denouncing also inequality and racism. It is noteworthy that rappers are also part of this oppressive system and may exhibit the same violent practices they denounce in their lyrics. Thus, rappers, besides being poets and singers of a reality, portrayed themselves as the social actors who engender the same movements and processes in which they participate.

Methodologically, this article employed the historical-discursive approach of Critical Discourse Analysis in accordance with Wodak $(2007,2009)$ and Wodak and Meyer's (2007) to investigate five categories within the selected material. The analysis 
was guided by the investigation of these categories, namely, referral or naming strategies; predication strategies; argumentative strategies; perspective, framing or representations of discourse; and intensification and mitigation strategies.

These categories allowed to unveil how violence presents itself as the social cement of the relationship between police officers and criminals. The distinct identification one group makes about itself is only possible because of the intrinsic relationship it engenders with the other. The movements and processes holding groups together are framed by specific forms of structural violence, historically sustained by inequality and racism that have become an immanence to Brazilian society.

This paper contributes and advances to understand how these different factors are integrative and integrated, constituent and constitutive of what is objectified in intergroup interactions. Moreover, it is pertinent to stress those interactions were not analyzed as theoretical-analytical abstractions, but as effectively concrete social relations.

Finally, we conclude with a reflection that traces back to the one put forward in the Introduction. Nowadays, rap music can no longer be deemed as a marginal musical rhythm or cultural manifestation. It has been integrated to a commercial mainstream that could potentially misrepresent it. However, it has remained a means to denounce and rebel against social problems, especially those related to the inequality present in the most different forms of racism, for example. Violence comes about as a social manifestation of unequal structural aspects at the bases of Brazilian society. In relational terms, violence becomes fundamental for consolidating the social realities taking place in Brazil. Therefore, regardless of whether we consider violence to be inescapable or not, its indepth study and understanding are essential for present as well as future struggles against its prolongations and radiations.

\section{REFERENCES}

ADORNO, S. Monopólio estatal da violência na sociedade brasileira contemporânea. In: S. MICELI (Org.). O que ler na ciência social brasileira 1970-2002. Sumaré, v. IV, p. 267-307, 2002a.

ADORNO, S. Exclusão socioeconômica e violência urbana. Sociologias, v. 8, p. 84-135, 2002 b.

ALMENDRA, D.; MORAES, P.R.B. O medo, a mídia e a violência urbana. A pedagogia política da segurança pública no Paraná. Revista Brasileira de Segurança Pública, v. 6, p. 266-280, 2012.

ALTHUSSER, L. Ideologia e aparelhos ideológicos de Estado. 3. ed. Lisboa: Editorial Presença/Martins Fontes, 1980.

CAMARGOS, R. Relatos sanguinários e sentimentos indigestos no rap de Facção Central. Música Popular em Revista, Campinas, ano 5, v. 1, p. 70-94, jul.-dez. 2017.

DURKHEIM, E. A divisão do trabalho social. São Paulo: Martins Fontes, 1999.

GOMES, M. A. "Discurso ou revólver" "Tá na hora da revolução" Diálogos anticoloniais e antirracistas entre o grupo de rap Facção Central, Achille Mbembe e Frantz Fanon. Em tempos de Histórias, v. 32, n.1, p. 44-66, 2018.

HELLAND, K. Mona AKA Sad Girl: A multilingual multimodal critical discourse analysis of music videos of a Japanese Chicana rap artist. Discourse, Context \& Media, v. 23, p. 25-40, 2018.

HOBSBAWM, E. A era dos extremos: o breve século XX. 1941-1991. São Paulo: Companhia das Letras, 1995.

LOUREIRO, B. O ativismo dos rappers e o "progresso intelectual da massa": uma leitura gramsciana do rap no Brasil. Rev. HISTEDBR On-line, Campinas, v.17, n.2 [72], p.419-447, abr./jun. 2017. 
RIGON, B.; FRANÇA, L. As periferias brasileiras como espaços de exceção: um genocídio cotidiano pela violência policial. Revista Profanações, v. 1, n. 2, p. 197-218, jul./ dez. 2014.

RICHARDSON, E. 'She was workin like foreal': Critical literacy and discourse practices of African American females in the age of hip hop. Discourse and Society, v. 18, n. 6, p.789-809, 2007.

SAMYN, H. M. Figurações do (anti-)herói épico em Tô ouvindo alguém me chamar dos Racionais MCs e Isso aqui é uma guerra do Facção Central. Estudos de Literatura Brasileira Contemporânea, n. 55, p. 223-237, set./dez. 2018.

TADDEO, C. E. A guerra não declarada na visão de um favelado. São Paulo: Edição do autor, 2012. TEPERMAN, R. Se liga no som: as transformações do rap no Brasil. São Paulo: Claro Enigma, 2015a, $177 \mathrm{p}$.

TEPERMAN, R. O rap radical e a "nova classe média". Psicologia USP, v. 26, n. 1, p. 37-42, 2015b.

WODAK, R. Discourses in European Union organizations: Aspects of access, participation, and exclusion. TEXT and TALK, v. 27, n.5-6, p.655-680, 2007.

WODAK, R. The discourse-historical approach. In: REISIGL, M.; WODAK, R. (Eds.), Methods of Critical Discourse Analysis. London: Sage Publications, 2009. p. 63-94.

WODAK, R.; MEYER, M. Critical discourse analysis: history, agenda, theory, and methodology. In: WODAK, R.; M. MEYER (Eds.). Methods for Critical Discourse Analysis. $2^{\text {nd }}$ rev. ed. London: Sage, 2009. p. 1-33.

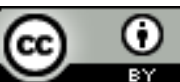

Este texto está licenciado com uma Licença Creative Commons Atribuição 4.0 Internacional.

LESSA, Bruno de Souza; SOUZA, Ana Clara Aparecida Alves de. "There is no white flag and no chance of going to jail!" - the violent relation between police and criminals in Facção Central's rap songs. Linguagem em

(Dis)curso - LemD, Tubarão, SC, v. 20, n. 1, p. 197-210, jan./abr. 2020. 